
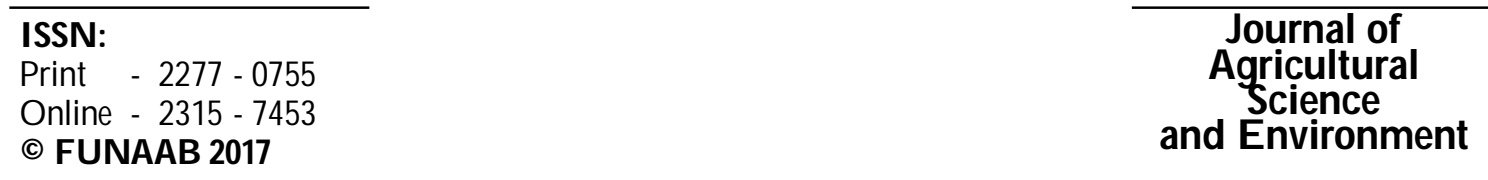

\title{
HABITAT USE ST RATEGY OF VERTEBRATES IN AN EMERGING NATURE RESERVE
}

\author{
*1A.L.A SHOTUYO , 0.A. JAYEOLA¹ AND I.A. AYODELE² \\ 1D epartment of Forestry and Wildlife Management, Federal University of Agriculture, \\ Abeokuta, Nigeria \\ 2D epartment of Wildlife and E cotourism Management, University of Ibadan \\ *Comesponding Author: shotuyoala@ funaab.edu.ng, Tel: 2348033455902.
}

\begin{abstract}
ABST RACT
The habitat use strategy of vertebrates in Alabata Strict Nature Reserve was studied. Twenty (20) sample plots of $25 \mathrm{~m} \times 25 \mathrm{~m}(0.062 \mathrm{ha})$ were laid at random over the total area of the study site for data collection. King Census and Line Transect methods were modified for this study using direct and indirect modes of wildlife stock assessment for an accurate collection of data due to the dense nature of the vegetation in some areas. One hundred and twenty-one vertebrate species, belonging to fifty-six families were recorded. Twenty-seven families were represented by just a single species each, while thirteen families had two species each. The family Colubridae was represented by ten species, while Rattudae and Sciuridae had a single species respectively. Birds were the most encountered (more than 60\%) followed by mammals (more than 20\%) while the Order Reptalia constitutes the remaining (less than 20\%). Food and cover requirements abound in the study area, which explains the availability of a variety of fauna species. There is a strong association between the environmental variables and animal species thus; distribution, performance and survival of the species are directly influenced by these variables. The Principal component analysis and Ordination shows that the ecosystem of the study site is not stable yet. This can be observed from the clustering of the animal species together in an attempt to make the best use of the environment. The maintenance of a healthy ecosystem is largely dependent on its management and control of activities of man and animals.
\end{abstract}

\section{INTRODUCTION}

Strict nature reserves and wilderness areas are protected areas that are created and managed mainly for the purposes of research or for the protection of large, unspoiled areas of wilderness. Their primary purpose is the preservation of biodiversity and as essential reference areas for scientific work and environmental monitoring (IUCN).

Protection of biodiversity can be achieved in strict nature reserve, ecological reserves, etc. These are areas created for the conservation of natural values, usually the known habitat of endangered species, threatened ecosystem, or representative samples of widespread communities.(Shotuyo, 2011).

The breaking up of terrestrial habitats is widespread in most parts of the world, and its negative effects have been well documented (e.g. Saunders \& al., 1991). Native species are lost from habitat fragments because of deforestation-related disturbance, 
restriction of population size, reduced immigration, edge effects and invasion of exotic species (Turner, 1996). Management of remaining undisturbed fragments has received detailed attention as the primary means for enhancing the conservation status of fauna in the fragmented landscape. This has been particularly true for forest fragments, which may contain localized or threatened biota and source populations for recolonizing rehabilitated lands (Saunders $\notin$ al., 1987; Turner and Corlett, 1996). Implicit in most discussions of fragment conservation is the assumption that habitat fragments provide food and shelter resources needed for the long-term maintenance of populations, even if the surrounding environment is not entirely hostile to movement and supports populations of some species at low densities (Dickman and Doncaster, 1989; Hansson \&al., 1995).

This study examines the survival strategies of vertebrate resources in Alabata Nature reserve, which allows them to cope with the prevailing emerging conditions of a nature reserve undergoing regeneration.

\section{METHODOLOGY}

\section{The study area}

The study area is contained in the 9,700 hectare land of the University of Agriculture, Abeokuta, situated north-eastern of Abeokuta, along Alabata road, (fig.1). The site is located between latitude 70 and $7058^{\text {! }}$ And Longitude $303^{!}$And 30 37! The site falls within the humid tropical lowland region with two distinct seasons. The longer wet season lasts for eight (8) months, from March - October and the shorter dry season lasts for four (4) months from November February. The area normally witness high rainfall at two periods of the year, i.e the peak period of June - July and September October. It has a mean annual rainfall of 1250 to $2500 \mathrm{~mm}$.

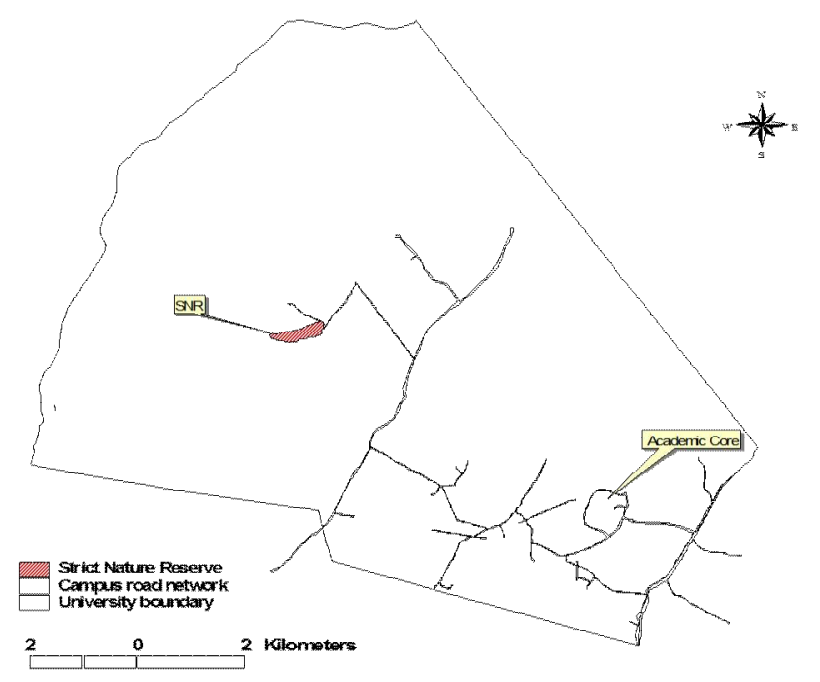

Fig. 1: Map Of the University of Agriculture showing the Study Area 
HABITAT USE STRATEGY OF VERTEBRATES IN AN ...

The mean monthly temperature ranges between $25.7{ }^{\circ} \mathrm{C}$ in July and $30.2^{\circ} \mathrm{C}$ in February. The lowest temperature is recorded in June and September. The relative humidity is high all year round. The most humid months coincides with the rainy season and the figure ranges between $60 \%$ and $80 \%$ from D ecember to February.

\section{Sampling Procedures}

Twenty (20) sample plots of $25 \mathrm{~m} \times 25 \mathrm{~m}$ (0.062ha) were laid based on observed richness in vegetation cover over the total area of the study site for data collection. For accuracy and ease in data collection, each plot of $25 \mathrm{~m} \times 25 \mathrm{~m}$ was further partitioned into 5 quadrates of equal sizes at the left and right sides of the centerline of each plot.

\section{Animal (Vertebrates) Survey}

King Census and Line Transect methods were modified for this study using direct and indirect modes of wildlife stock assessment for an accurate collection of data due to the dense nature of the vegetation in some areas. Direct count method was used for all animals sighted during the laying of plots. Animal survey was carried out within the plots and a checklist of all animal species found in the study area was made. The indirect method of sampling was also used. All indicators of animal presence or activities in the plots sampled were recorded.

\section{Vegetation Survey}

Total enumeration was carried out in each sample plot for all the trees and shrubs.
These provided the floristic data for the study. The specimens that cannot be identified on the field were taken to a standard herbarium (Forestry Research Institute Ibadan) for proper identification.All ground flora with height below $1 \mathrm{~m}$ and dbh of $\leq 5 \mathrm{~cm}$ were enumerated for their percentage abundance in each plot.

\section{RESULT AND DISCUSSION}

One hundred and eighteen (118) plant species (Table 1) being members of fifty-three families were found to constitute the major vegetation of the study site. The Gramineae contain the most number of species (nineteen) followed by Papilionaceae (nine) and Euphorbiaceae with eight species (Table 2). Thirty-one shrub species (Table 3) were collected indicating the modification of the vegetation to a derived savannah ecosystem. Dicotyledons accounted for more than 80 percent of the ecosystem (Figure 3). Trees like Blighia sapida, Carda millerii and Danidla diver etc provides shades and comforts in quite many parts of the Nature Reserve.

One hundred and twenty-one (121) vertebrate species, belonging to fifty-six (56) families were recorded. (table 4). Twenty-seven families were represented by just a single species each, while thirteen families had two species each. (table 5). The family Cdubridae was represented by ten species, while Rattudae and Saunidae had a single species respectively. Birds were the most encountered (more than 60\%) followed by mammals (more than 20\%) while the other Reptalia constituted the remaining (less than 20\%). 
Table 1: Plant Species Identified in the Study site

\begin{tabular}{llll}
\hline S/ N & Botanical Name & Family & Local Name \\
\hline 1. & Acridocarpus smeathmannii & Malphighiaceae & G bogbori, Ogo-Igbo \\
2. & Acroceras zizanioides & Gramineae & Iye-Etu \\
3. & Agelaca oblique & Connaraceae & Esura, O kun \\
4. & Aidia genipiflora & Rubiaceae & \\
5. & Albizia zygia & Mimosaceae & Ayinre-weere,Ayunre \\
6. & Alternanthera pungens & Amaranthaceae & Danguro \\
7. & Alternanthera sessilis & Amaranthaceae & Danguro \\
8. & Amgylocalryx menostrachyus & Labiatae & \\
9. & Andropogon gayanus & Gramineae & Eruwa-funfun \\
10. & Andropogon tectorum & Gramineae & Eruwa-dudu \\
11. & Annona senegalensis & Annonaceae & Abo \\
12. & Argyreia nivosa & Convolvulaceae & \\
13. & Blepharis maderaspatensis & Acathaceae & Ojusaaju \\
14. & Blighia sapida & Sapindaceae & Isin \\
15. & Blighia unijugata & Sapindaceae & Ako-isin \\
16. & Brachiaria atrovirens & Gramineae & Yoyoka \\
17. & Brachiaria villosa & Gramineae & Agbado-esin \\
18. & Caesalpina bonduc & Caescalpiniaceae & Sayo, Ayo \\
19. & Cajanus cajan & Papilionaceae & Otili \\
20. & Canna bidentata & Cannaceae & Ido \\
\hline
\end{tabular}


HABITAT USE STRATEGY OF VERTEBRATES IN AN ...

\begin{tabular}{|c|c|c|c|}
\hline 21. & Cassia rotundifolia & Ceasalpinaceae & Epa ile \\
\hline 22. & Cassia tora & Ceasalpinaceae & Eru asunundegbe \\
\hline 23. & Ceratotheca sesamoidea & Pedaliaceae & Eku \\
\hline 24. & Chassalia kolly & Rubiaceae & Tutugbo \\
\hline 25. & Chochlospermum planchoni & Cochlospermaceae & \\
\hline 26. & Chrysophylum albidum & Sapotaceae & Agbalumo \\
\hline 27. & Cinna indica & Cannaceae & \\
\hline 28. & Cissampelos owariensis & Menispermaceae & Jenjokoo \\
\hline 29. & Cissus araliodies & Vataceae & Abeekonna marun-un \\
\hline 30. & Codianum veriegatum & Euphorbiaceae & \\
\hline 31. & Combretum racemosum & Combretaceae & Ogan-ibule \\
\hline 32. & Combretum smeathmanii & Combretaceae & Okan \\
\hline 33. & Comelina nigritana & Commelinaceae & Iyetakoko \\
\hline 34. & Cordia millenii & Boraginaceae & Omo \\
\hline 35. & Cordia platythrsa & Boraginaceae & Akoledo \\
\hline 36. & Costus afer & Zingiberaceae & Ireke-O mode \\
\hline 37. & Crotolaria retusa & Papilionaceae & Saworo \\
\hline 38. & Cyathula prostrate & Amaranthaceae & Sewerepepe \\
\hline 39. & Dactyloctenium aegytium & Gramineae & \\
\hline 40. & D albergia hostiles & Papilionaceae & Ogun-aja \\
\hline 41. & Dalbergiella welweitchi & Papilionaceae & Elemosoo \\
\hline 42. & D aniella oliveri & Papilionaceae & Iya \\
\hline 43. & D esmodium riflorum & Papilionaceae & Emo \\
\hline 44. & Digitaria horizontalis & Gramineae & Eeran oko \\
\hline 45. & D iscorea preussi & Discoreaceae & Ewo \\
\hline 46. & Ehretia cymosa & Boraginiaceae & Jaoke \\
\hline 47. & Eleusine indica & Gramineae & Gbegi \\
\hline 48. & Emilia praetermisa & Astraceae & Odundun \\
\hline 49. & Entada abyssinicca & Mimosaceae & Gbengbe \\
\hline 50. & Eragrostis tremula & Gramineae & Agbado-esin \\
\hline 51. & Eriosema glomeratum & Papilionaceae & Roro \\
\hline
\end{tabular}




\begin{tabular}{|c|c|c|c|}
\hline 52. & Erythrina senegalensis & Lpapilionaceae & Ologbosere \\
\hline 53. & Euphorbia hyssopifolia & Euphorbiaceae & Oro adete \\
\hline 54. & Ficus ingens & Moraceae & Oba-Odan \\
\hline 55. & Ficus mucuso & Moraceae & Obobo \\
\hline 56. & Funtumia Africana & Apocynaceae & Ire \\
\hline 57. & Furcraea gigantean & Agavaceae & \\
\hline 58. & Glyphaea brevis & Tiliaceae & Atori \\
\hline 59. & Gossypium barbadense & Euphorbiaceae & O wu-elepa \\
\hline 60. & Hisbiscus sabdarrifa & Malvaceae & Isapa \\
\hline 61. & Holoptelia grandis & Ulmaceae & Ayo \\
\hline 62. & Hymonocardia acida & Hymnenocardiaceae & Orupa \\
\hline 63. & Hyparrhenia involucrate & Gramineae & \\
\hline 64. & Hyparrhenia subplumosa & Gramineae & \\
\hline 65. & Icacina tricantha & Icacinaceae & Gbegbe \\
\hline 66. & Impereta cylindrical & Gramineae & Ekan \\
\hline 67. & Ipomoea heterotricha & Convolvulaceae & Jeminhoo \\
\hline 68. & Jassminum obtusifolium & Olaceae & \\
\hline 69. & Jatropha mullifida & Euphorbiaceae & Lapalapa \\
\hline 70. & Laggera pterodonta & Astraceae & Oorungo \\
\hline 71. & Mallotus subulatus & Euphorbiaceae & Apaluwore \\
\hline 72. & Manihot glaziovii & Euphorbiaceae & Igi-isana \\
\hline 73. & Mariscus alternifolius & Сyperaceae & Ikeregun \\
\hline 74. & Merrennia kentrocaulis & Convolvulaceae & Atewegbore \\
\hline 75. & Mitracarpus scaber & Rubiaceae & Irawo-ile \\
\hline 76. & Mondora tennifolia & Annonaceae & Lakosin \\
\hline 77. & Newbouldia laevis & Bignonaceae & Akoko \\
\hline 78. & Ochra afzeli & Ochroceae & \\
\hline 79. & Panicum brevifolium & Gramineae & Eeran-esin \\
\hline 80. & Parinari curatelifolia & Chrysobalanaceae & Abo-idofin \\
\hline 81. & Parquetina nigrecens & Periplocaceae & Ogbo \\
\hline 82. & Passiflora foetida & Passifloraceae & \\
\hline 83. & Pedilanthus tithymalodies & Euphorbiaceae & \\
\hline
\end{tabular}


HABITAT USE STRATEGY OF VERTEBRATES IN AN ...

\begin{tabular}{|c|c|c|c|}
\hline 84. & Pennisetum polystachon & Gramineae & Ilosun \\
\hline 85. & Pennisetum purpureum & Gramineae & Eesu \\
\hline 86. & Petiveria alliacea & Phytolaceae & Awogba \\
\hline 87. & Physalis micrantha & Solanaceae & Efopo \\
\hline 88. & Polycarpaea linearifolia & Euphorbiaceae & Eyin-ire \\
\hline 89. & Pouzolzia guineensis & Urticaceae & Abolokopiran \\
\hline 90. & Rhigiocarya racemifera & Menispermaceae & Lagbolagbo \\
\hline 91. & Rhynchelytrum repens & Gramineae & Eeran-eye \\
\hline 92. & Ritchiea longipedicellata & Capparidaceae & Ologbe-kuyan \\
\hline 93. & Rothamannia urcelliformis & Rubiaceae & Buje \\
\hline 94. & Rottboellia exaltata & Gramineae & Holo \\
\hline 95. & Sanseviera trifasciata & Agavaceae & Oja-ikooko \\
\hline 96. & Schizachrium sanguineum & Gramineae & Bere \\
\hline 97. & Schrankia leptiocarpa & Mimosaceae & \\
\hline 98. & Scleria depressa & Cyperacae & Emee \\
\hline 99. & Secamone afzeli & Asclepiadaceae & Arilu \\
\hline 100. & Securidaca longepedunculata & Polygalaceae & Ipeta \\
\hline 101. & Senna alata & Caesalpiniaceae & \\
\hline 102. & Senna hirsute & Caesalpiniaceae & \\
\hline 103. & Solenostemon monostachyus & Labiatae & Aranpolo \\
\hline 104. & Sorindeia warneckei & Anacardiaceae & Afunsese \\
\hline 105. & Spilanthes filicaulis & Compositae & Awerepepe \\
\hline 106. & Spondias monbin & Anacardiaceae & Iyeye \\
\hline 107 & Sporobolus pyramidalis & Gramineae & \\
\hline 108. & Stachytarpheta cayennesis & Verbernaceae & Agogo igun \\
\hline 109. & Striga mucrantha & Scrophulariaceae & \\
\hline 110. & Strychnos spinosa & Loganiaceae & Atako \\
\hline 111. & Thevetia peruviana & Apocynaceae & Olomiojo \\
\hline 112. & Triplochiton scleroxylon & Sterculiceae & Arere \\
\hline 113. & Triumfetta rhomboidea & Tiliaceae & Boko-pupa \\
\hline 114. & Uraria picta & Papilionaceae & Alupayida \\
\hline 115. & Vigna racemosa & Papilionaceae & Gbomogungi \\
\hline 116. & Vigna triloba & Papilionaceae & Eree \\
\hline 117. & Vitellaria paradoxa & Sapotaceae & Emi \\
\hline 118. & Wassadula amplissima & Malvaceae & Ewefuru \\
\hline
\end{tabular}


A.L.A SHOTUYO , O.A.JAYEOLA AND I.A. AYODELE

Table 2: Distribution of Species according to Families

\begin{tabular}{|c|c|}
\hline Family & N umber of Species \\
\hline Acathanceae & 1 \\
\hline Agavaceae & 2 \\
\hline Amaranthaceae & 3 \\
\hline Anacardiaceae & 2 \\
\hline Annonaceae & 2 \\
\hline Apocynaceae & 2 \\
\hline A sclepiadaceae & 1 \\
\hline Astraceae & 2 \\
\hline Bignonaceae & 1 \\
\hline Boraginaceae & 3 \\
\hline Caesalpinaceae & 3 \\
\hline Capparidaceae & 1 \\
\hline Ceasalpinaceae & 2 \\
\hline Chrysobalanaceae & 1 \\
\hline Cocchlospermaceae & 1 \\
\hline Combretaceae & 2 \\
\hline Commelinaceae & 1 \\
\hline Compositae & 1 \\
\hline Connaraceae & 1 \\
\hline Convolvulaceae & 3 \\
\hline Cyperaceae & 2 \\
\hline D iscoreaceae & 1 \\
\hline Euphorbiaceae & 8 \\
\hline G ramineae & 19 \\
\hline Hymnenocardiaceae & 1 \\
\hline Icacinaceae & 1 \\
\hline Labiatae & 2 \\
\hline Loganiaceae & 1 \\
\hline Lpapilionaceae & 2 \\
\hline Malvaceae & 2 \\
\hline
\end{tabular}




Malvaceae
Merispermaceae
Mimosaceae
Moraceae
O chroceae
Olaceae
Papilionaceae
Papsifloraceae
Pedaliaceceae
Periplocaceae
Phytolaceae
Polygalaceae
Rubiaceae
Sapindaceae
Sapotaceae
Scrophulariaceae
Solanaceae
Sterculiceae
Tiliaceae
Ulmaceae
Urticaceae
Vataceae
Zingiberaceae

2

2

3

2

1

1

9

1

1

1

1

1

4

2

2

1

1

1

2

1

1

1

1

1 


\section{Table 3: Habit of Plant Species}

\begin{tabular}{ll}
\hline Botanical Name & Habit \\
\hline Acridocarpus smeathmannii & Shrub \\
Acroceras zizanioides & Grass \\
Agelaca oblique & Climber \\
Aidia genipiflora & Tree \\
Albizia zygia & Tree \\
Alternanthera pungens & Herb \\
Alternanthera sessilis & Herb \\
Amgylocalryx menostrachyus & Shrub \\
Andropogon gayanus & Grass \\
Andropogon tectorum & Grass \\
Annona senegalensis & Tree \\
Argyreia nivosa & Climber \\
Blepharis maderaspatensis & Herb \\
Blighia sapida & Tree \\
Blighia unijugata & Tree \\
Brachiaria atrovirens & Grass \\
Brachiaria villosa & Grass \\
Caesalpina bonduc & Herb \\
Cajanus cajan & Shrub \\
Canna bidentata & Herb \\
Cassia rotundifolia & Herb \\
Cassia tora & Shrub \\
Ceratotheca sesamoidea & Herb \\
Chassalia kolly & Shrub \\
Chochlospermum planchoni & Shrub \\
Chrysophylum albidum & Herb \\
Canna indica & Shrub \\
Cissampelos owariensis & Climber \\
Cissus araliodies & Climber \\
Codianum veriegatum & Shrub \\
Combretum racemosum & Climber \\
\hline J. Agic sci. \& Env. 2017, & 59 \\
\hline $50-80$ & \\
\hline
\end{tabular}


HABITAT USE STRATEGY OF VERTEBRATES IN AN ...

\begin{tabular}{ll}
\hline Combretum smeathmanii & Scrambling Shrub \\
Commelina nigritana & Herb \\
Cordia millenii & Tree \\
Cordia platythrsa & Tree \\
Costus afer & Herb \\
Crotolaria retusa & Herb \\
Cyathula prostrate & Herb \\
D actyloctenium aegytium & Grass \\
D albergia hostilis & Scrambling Shrub \\
D albergiella welweitchi & Scrambling Shrub \\
D aniela olliveri & Tree \\
D esmodium riflorum & Shrub \\
Digitaria horizontalis & Grass \\
D iscorea preussi & Climber \\
Ehretia cymosa & Herb \\
Eleusine indica & Grass \\
Emilia praetermisa & Herb \\
Entada abyssinicca & Tree \\
Eragrostis tremula & Grass \\
Eriosema glomeratum & Shrub \\
Erythrina senegalensis & Tree \\
Euphorbia hyssopifolia & Herb \\
Ficus ingens & Tree \\
Ficus mucuso & Tree \\
Funtumia Africana & Tree \\
Furcraea gigantean & Shrub \\
G lyphaea brevis & Shrub \\
G ossypium barbadense & Shrub \\
Hisbiscus sabdarrifa & Herb \\
Holoptelia grandis & Tree \\
Hymonocardia acida & Tree \\
Hyparrhenia involucrate & Grass \\
Hyparrhenia subplumosa & Grass \\
& \\
\hline &
\end{tabular}




\begin{tabular}{ll}
\hline Icacina tricantha & Shrub \\
Impereta cylindrical & Grass \\
Ipomoea heterotricha & Creeping Herb \\
Jassminum obtusifolium & Scrambling Shrub \\
Jatropha mullifida & Shrub \\
Laggera pterodonta & Herb \\
Mallotus subulatus & Shrub \\
Manihot glaziovii & Shrub \\
Mariscus alternifolius & Sedge \\
Merrennia kentrocaulis & Creeping Herb \\
Mitracarpus scaber & Herb \\
Mondora tennifolia & Tree \\
Newbouldia laevis & Tree \\
Ochra afzeli & Shrub \\
Panicum brevifolium & Grass \\
Parinari curatelifolia & Tree \\
Parquetina nigrecens & Climber \\
Passiflora foetida & Creeping Herb \\
Pedilanthus tithymalodies & Herb \\
Pennisetum polystachon & Grass \\
Pennisetum purpureum & Grass \\
Petiveria alliacea & Herb \\
Physalis micrantha & Herb \\
Polycarpaea linearifolia & Herb \\
Pouzolzia guineensis & Herb \\
Rhigiocarya racemifera & Climber \\
Rhynchelytrum repens & Grass \\
Ritchiea longipedicellata & Shrub \\
Rothamannia urcelliformis & Tree \\
Rottboellia exaltata & Grass \\
Sanseviera trifasciata & Herb \\
Schizachrium sanguineum & Grass \\
Schrankia leptiocarpa & Herb \\
\hline J Agnc, sci \& Env. $2017,17(50-80$ & 61 \\
\hline
\end{tabular}


Scleria depressa

Secamone afzeli

Securidaca longepedunculata

Senna alata

Senna hirsute

Solenostemon monostachyus

Sorindeia warneckei

Spilanthes filicaulis

Spondias monbin

Sporobolus pyramidalis

Stazchytarpheta cayeneesis

Striga mucrantha

Strychnos spinosa

Thevetia peruviana

Triplochiton scleroxylon

Triumfetta rhomboidea

Uraria picta

Vigna racemosa

Vigna triloba

Vitellaria paradoxa

Wassadula amplissima
Herb

Climber

Tree

Shrub

Shrub

Shrub

Scrambling Shrub

Herb

Tree

Grass

Herb

Herb

Tree

Tree

Tree

Shrub

Shrub

Climber

Climber

Tree

Shrub

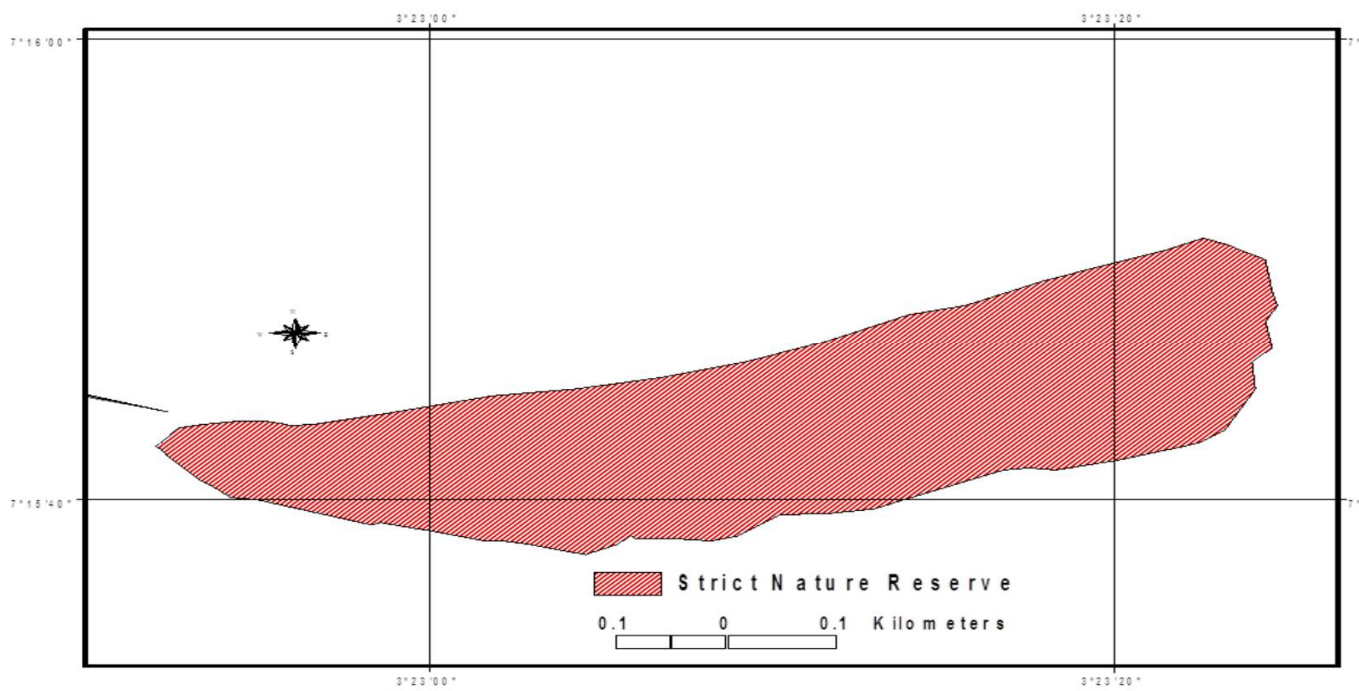

Fig. 2: Map of Study Area 
贾

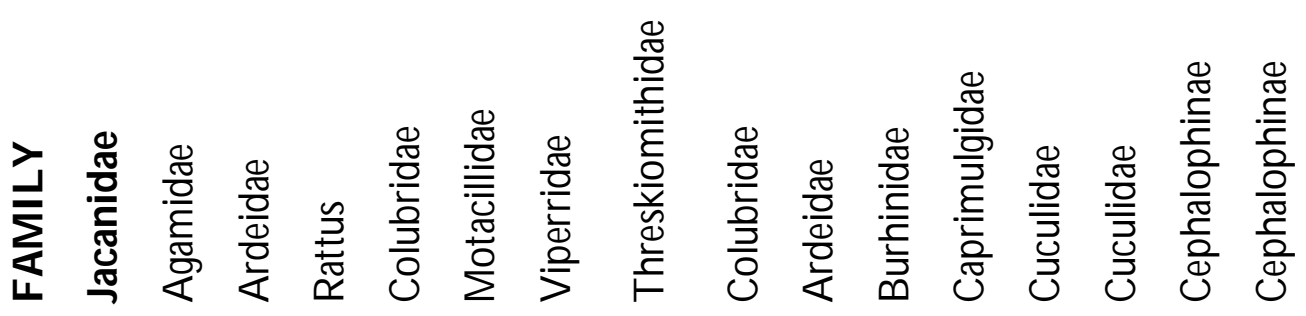

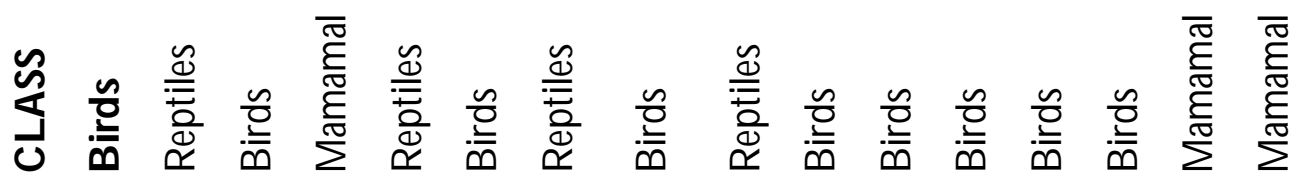

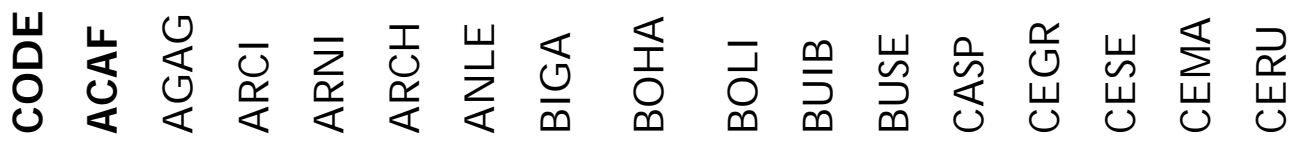

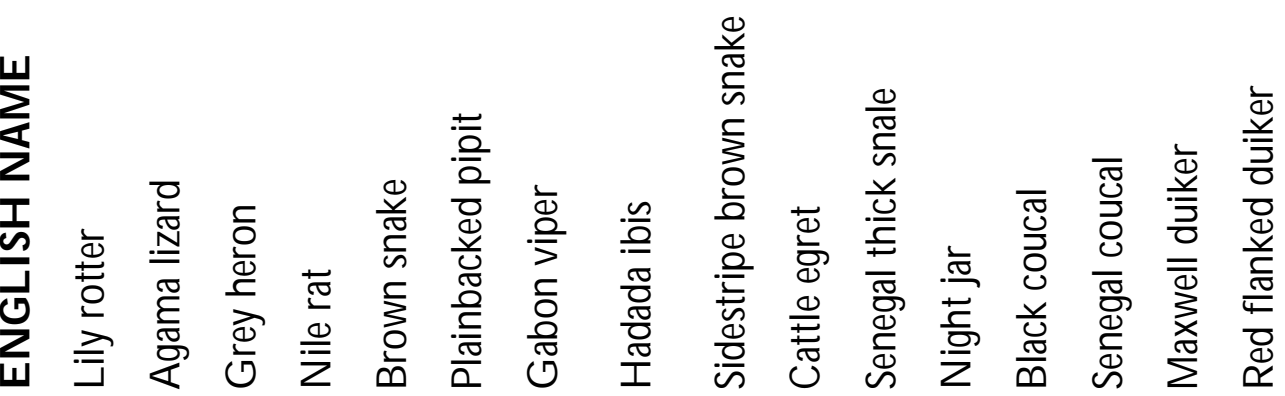

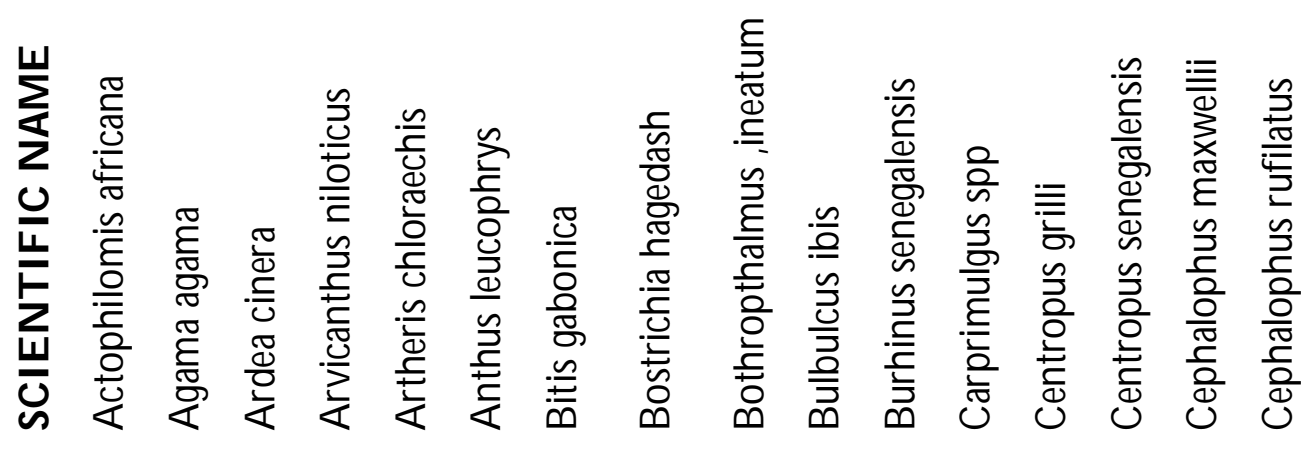
$\dot{0}$
$Z$
0
0 


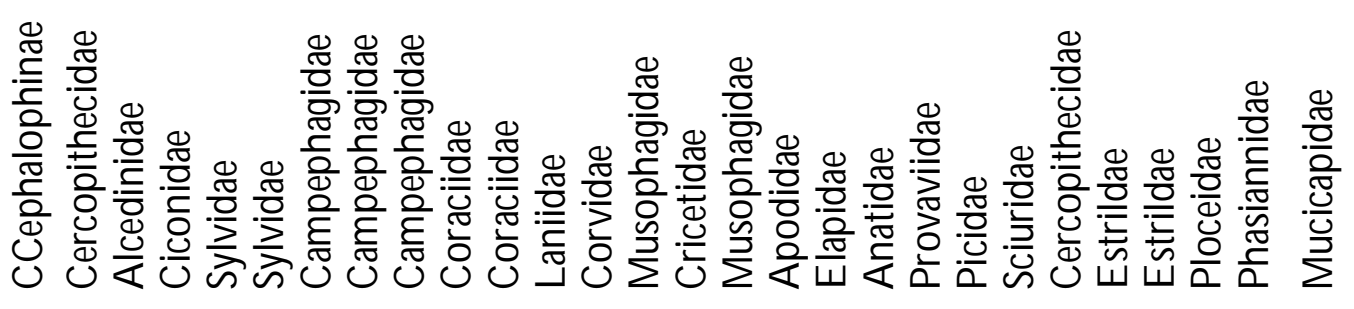

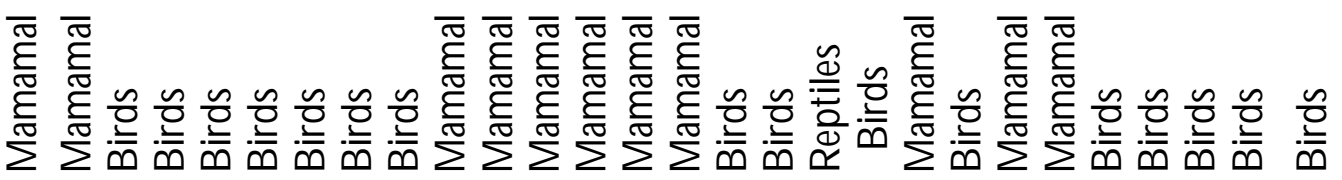

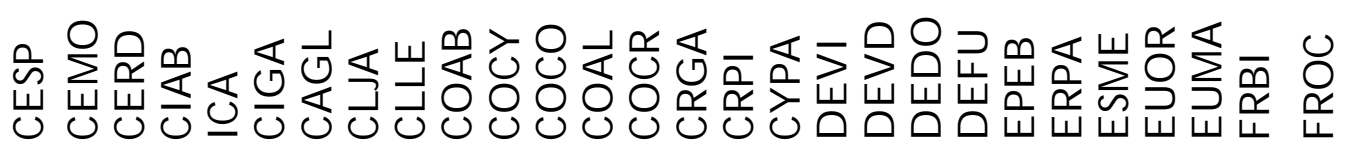
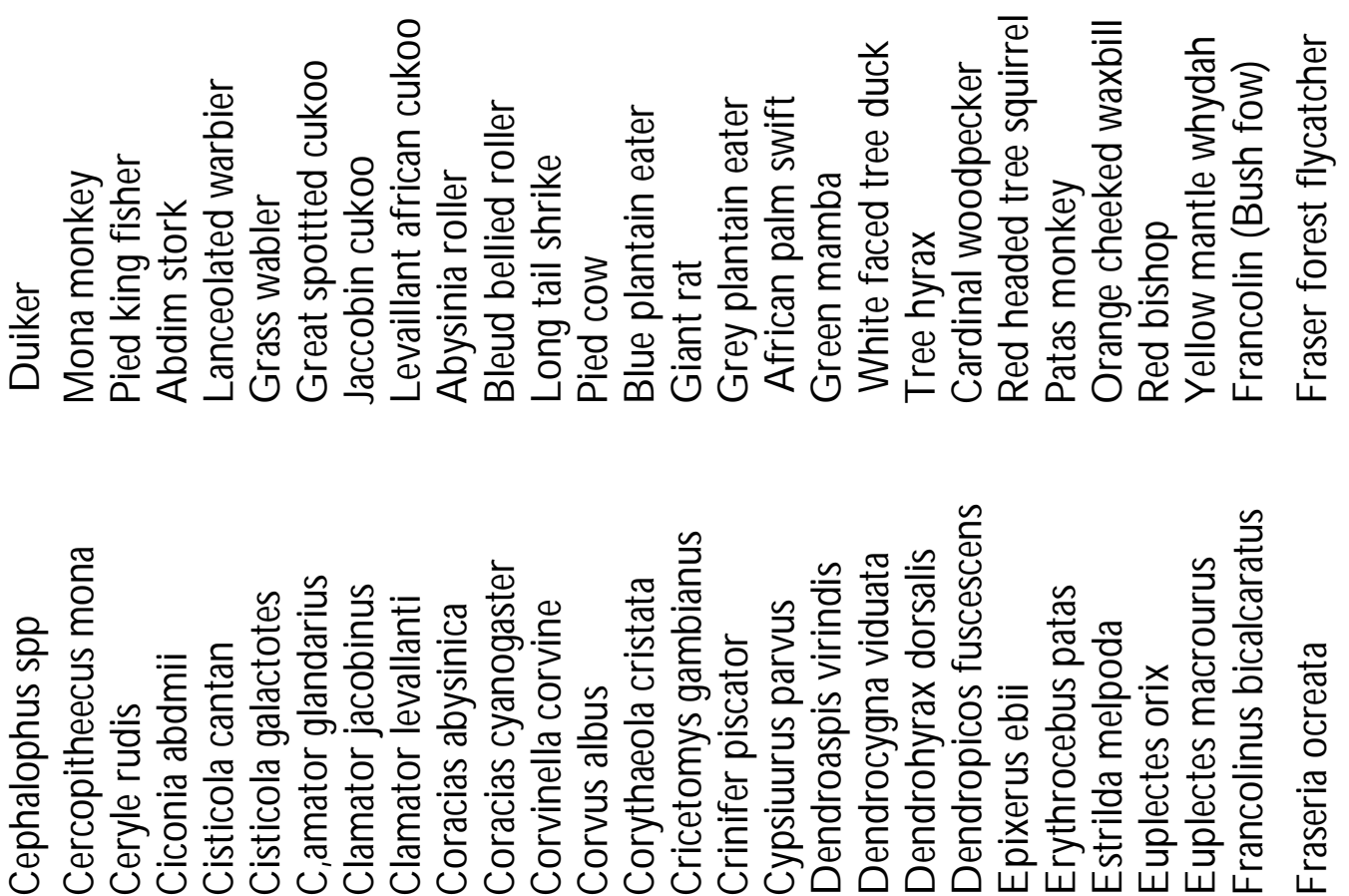

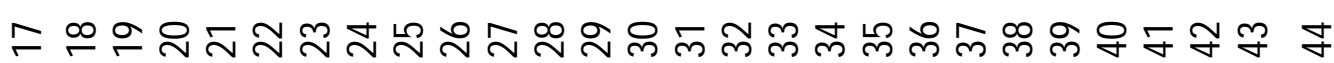




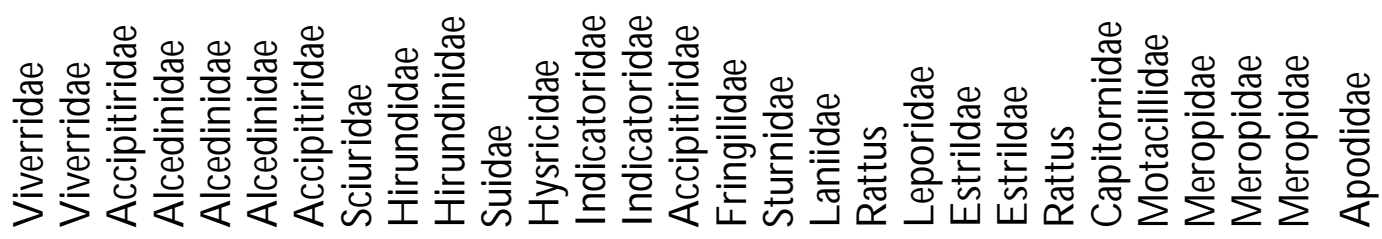

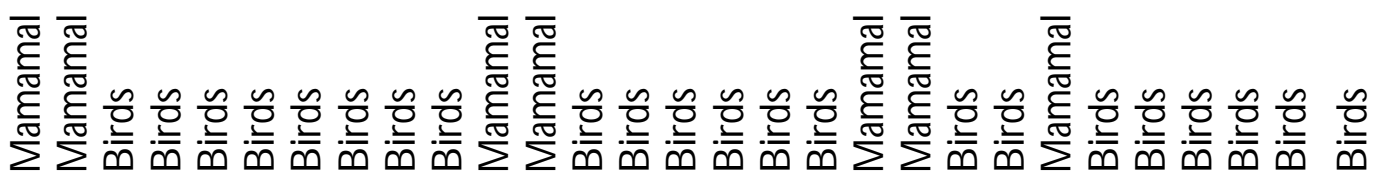

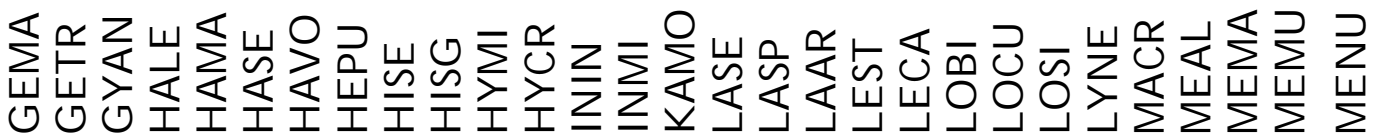
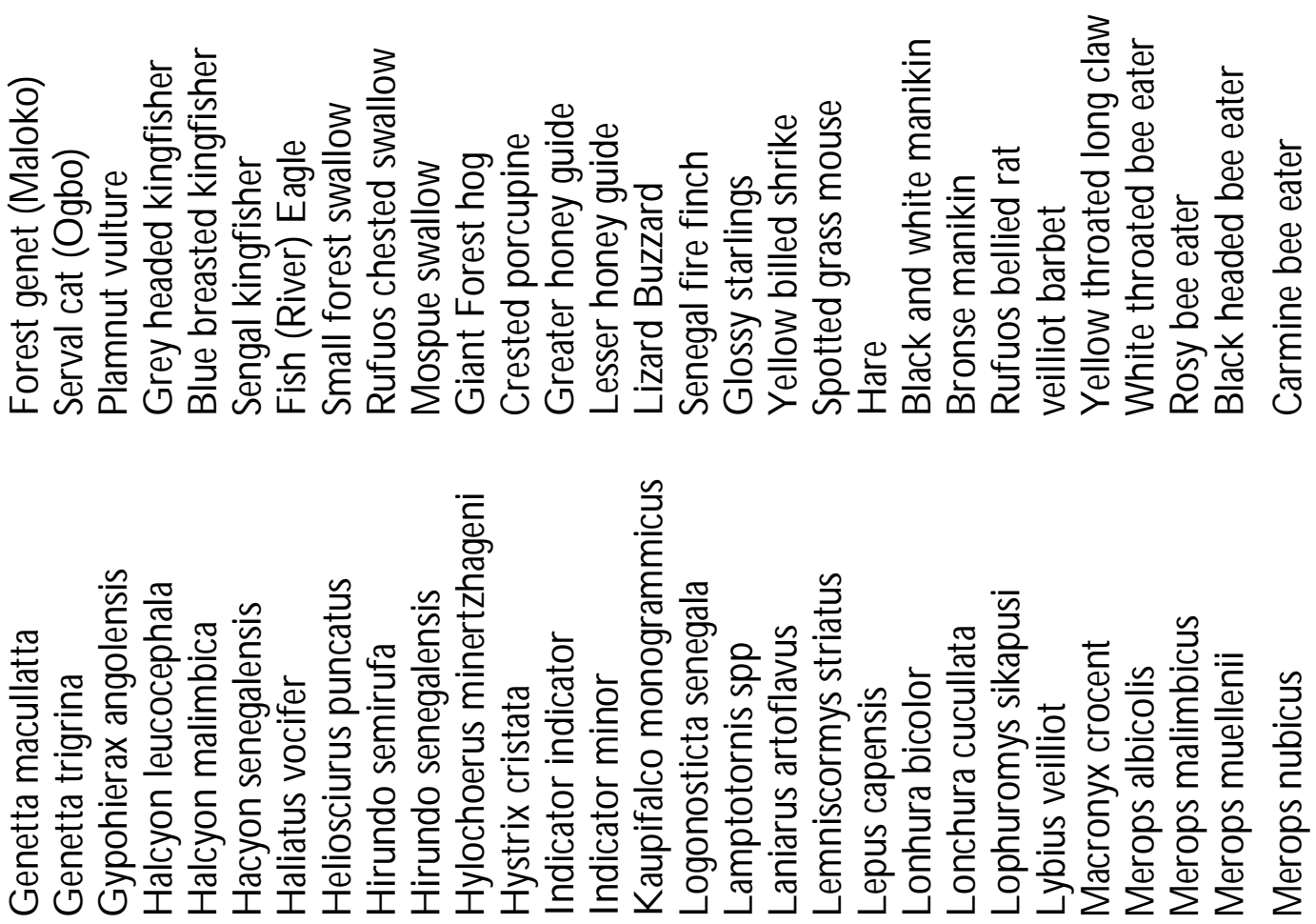

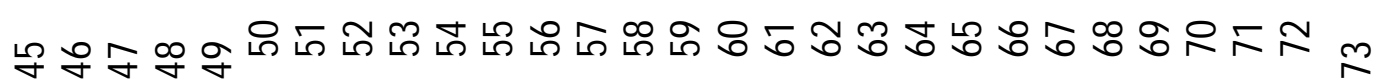




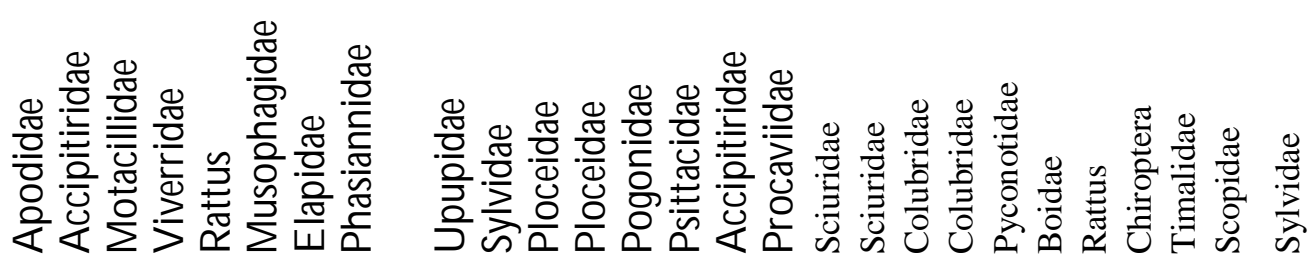

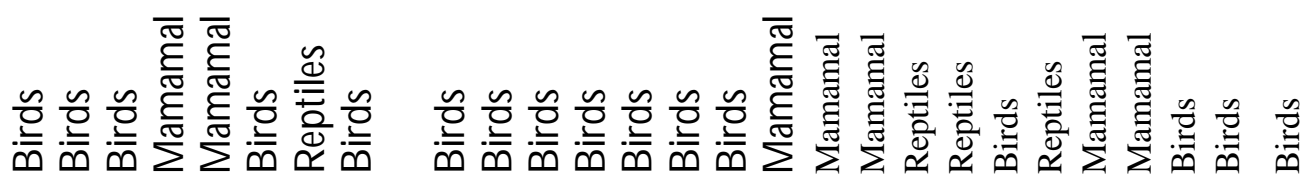

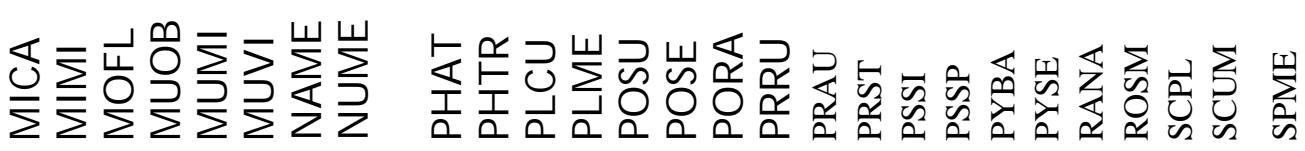
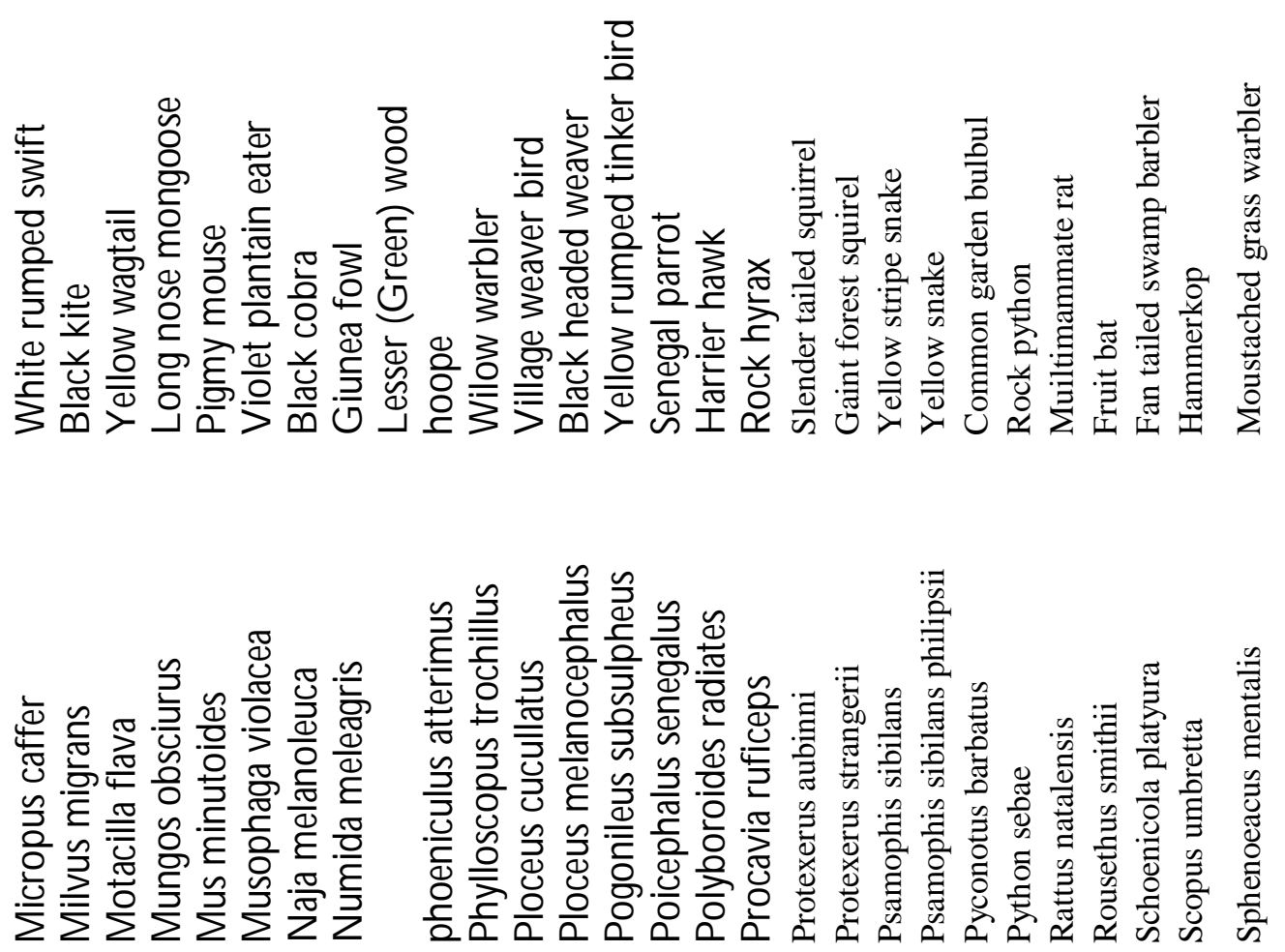

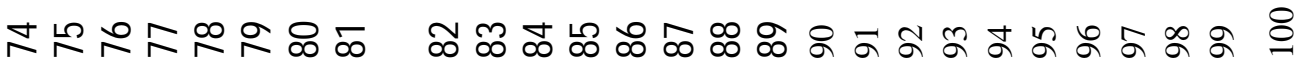




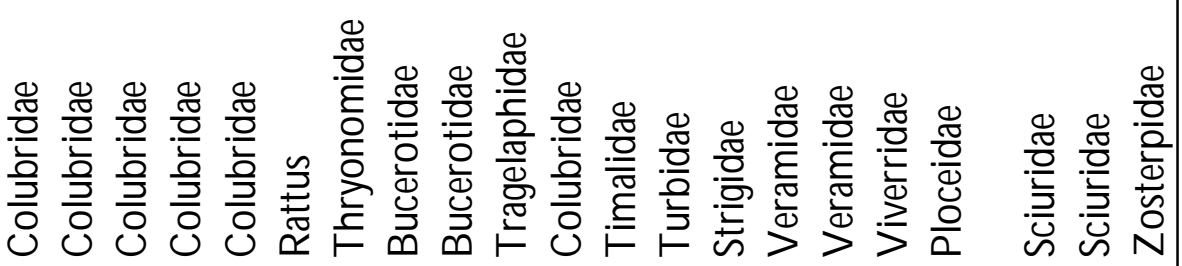

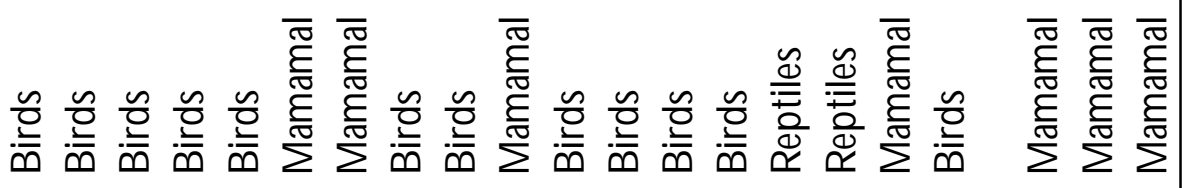

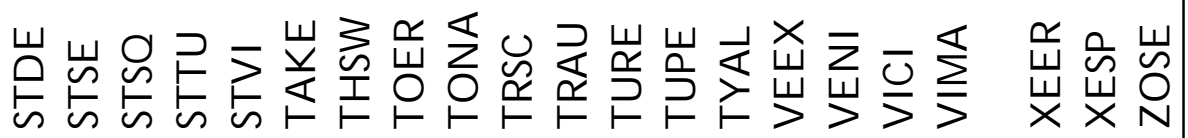

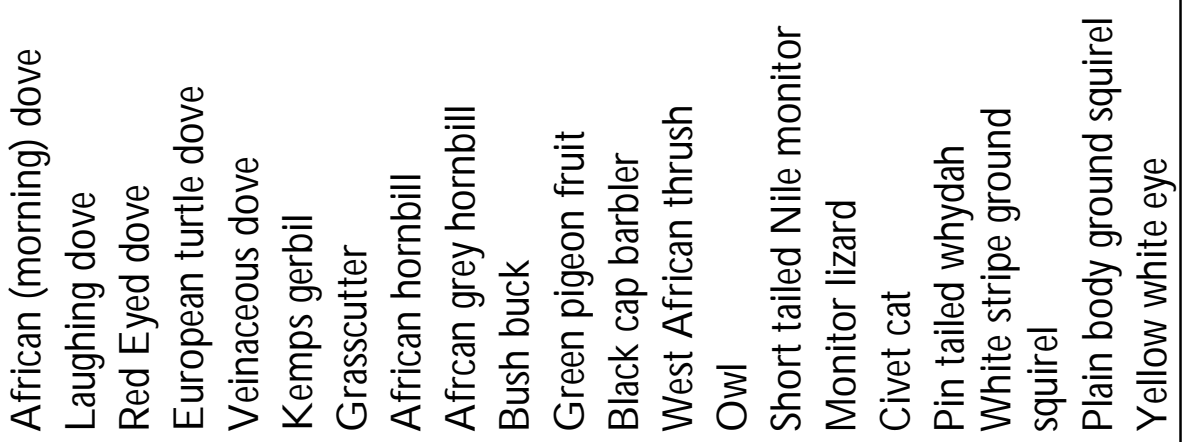

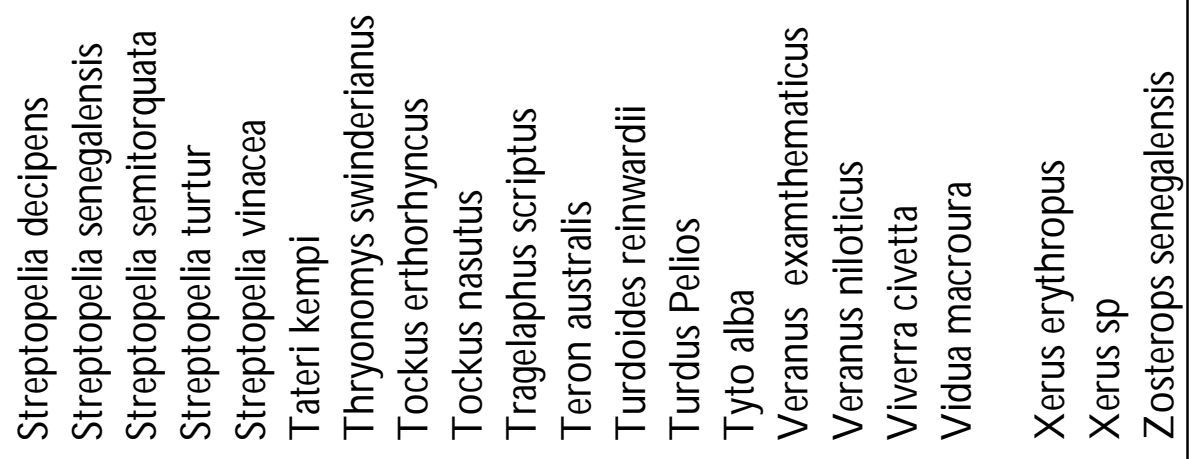

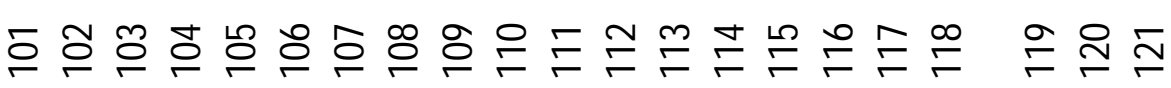


HABITAT USE STRATEGY OF VERTEBRATES IN AN ...

Table 5: Distribution of Vertebrate Species according to Families

\begin{tabular}{ll}
\hline Family & N umber of Species \\
\hline Accipitridae & 5 \\
Agamidae & 1 \\
Alcedinidae & 4 \\
Anatidae & 1 \\
Apodidae & 3 \\
Ardeidae & 2 \\
Boidae & 1 \\
Brogonidae & 2 \\
Bucerotidae & 2 \\
Burhinidae & 1 \\
Campephagidae & 3 \\
Capitornidae & 1 \\
Caprimalgidae & 1 \\
Cephalophinae & 3 \\
Cercopithecidae & 3 \\
Chiroptera & 1 \\
Ciconidae & 1 \\
Colubridae & 10 \\
Coraciidae & 2 \\
Corvidae & 1 \\
Cuculidae & 2 \\
Elapidae & 2 \\
Estrildae & 4 \\
Fringilidae & 1 \\
Hirundinidae & 2 \\
Hysricidae & 1 \\
Indicatoridae & 2 \\
Jacanidae & 3 \\
Laniidae & 3 \\
Meropidae & \\
Motacillidae & \\
& \\
& \\
&
\end{tabular}




\begin{tabular}{ll}
\hline Mucicapidae & 1 \\
Musophagidae & 3 \\
Phasiamidae & 2 \\
Picidae & 1 \\
Ploceidae & 4 \\
Procaviidae & 1 \\
Psittacidae & 2 \\
Pyconotidae & 1 \\
Rattudae & 7 \\
Sciuridae & 6 \\
Scopidae & 1 \\
Strigadae & 1 \\
Sturnidae & 1 \\
Suidae & 1 \\
Sylvidae & 4 \\
Threskiomithidae & 1 \\
Thryonomidae & 1 \\
Timalicae & 2 \\
Tragelaphidae & 1 \\
Turbidae & 1 \\
Upupidae & 2 \\
Varamidae & 1 \\
Viperridae & 1 \\
Viverridae & 4 \\
Zosterpidae & 1 \\
\hline
\end{tabular}

The level of species diversity recorded for plants and animals in the study area is high; one hundred and eighteen (118) plant species from 44 families and 40 animal species from 31 families. According to Richards (1952), the humid tropical forest has the richest and most heterogeneous faunal and floristic diversity which developed largely because of the favourable conditions of climate and other factors that favours the abundance of species in all seasons. The study area has the diversity of plants recorded because it is free from hunting pressures, thus serving as a refuge for the animals. Onadeko and Meduna
(1985) reported abundance of animals in the protected sites than sites that were unprotected. Also the high plant species diversity recorded in the study area (table 6) can be attributed to the absence of agricultural practices and other development activities. Grasscutters (Thryonamys swinderianus) and giant rats (Crictomys gambianus) were most abundant in the study area because there were favourable food resources as well as cover adequate for their requirments were present.

The results of this study indicate that Danidla diver, Anoma senegalensis, Briddia micrantha and 
HABITAT USE STRATEGY OF VERTEBRATES IN AN ...

Fiaus capenssis were the most abundant tree species. According to Kupchella and Hyland (1993), the edaphic, climatic and topographic factors determine the type and distribution of plant species that will survive in an area. The plants in turn control these factors and create a microclimate that ensures a normal physical environment that promotes their survival. Happold (1987), also reported that in certain cases, the animals present in a vegetation could be a major determinant of the type of vegetation that will persist in an area because of their mode of utilization of the plants for food and cover. Therefore, the relationship that exists between most of the plants and animals indicated by the biplots promotes a stable ecological system for their survival.

Animals in the order rodentia, especially cane rat (Thryonomys swindeianus), giant rat (Crictomys gambianus) and ground squirrel (Xeus eythropus) were the most abundant in the study area. Indices of their activities include feeding remains, droppings and burrows.

The Maxwell duiker (Cephalqus maxwelli) was also recorded in appreciable number. Happold (1973) and Roberts (1986) stated that the trophic ecology and need for protection against predators of animal species in an area explains the basis for their habitat distribution.

Dasmann (1985) also reported that the availability of food, water and cover are the major determinants of wild animal occurrence and distribution in an area. This explains the distributions of animals on the biplot based on their feeding and cover requirements.

The Cane rats were predominant in areas with dense grasses and rampant herbaceous vegetation where there is also good cover. They feed on thick stemmed grasses and occasionally on tree barks (Happold, 1987) as shown by their runways, feacal droppings and feeding remains. The Giant rat (Crictamys gambianus) feed on fruits, vegetables, seeds, maize, yams, and oil palm nuts and this explains their abundance because some of these requirements are in abundant supply in the study area.

Also, the Ground squirrel, found widely in the study area live habitually on the ground especially in burrows and feed on seeds, roots and bulbs (Ewer, 1969). The areas where they are mostly found in the study area is rich in these requirements. The Maxwell duiker lives in wooded and grassland savanna where there are small thickets and undergrowth where they can seek cover (Happold, 1973). Their diet consists of leaves and herbs and young plant. These food and cover requirements abound in the study area where they browse on the young stems of these trees and shrubs and hide in the dense undergrowth.

The Hares (Lepus capensis) live in drier habitats where the vegetation is heavily grazed and grasses are short and spouting (Happold, 1987). They are found to predominate in such vegetation on the study site. This habitat preference causes them to live in areas otherwise uninhabitable for other browsers and grazers and explains the large dispersion of their position on the northern portion of the study site where they occur away from the other wildlife species occurring in the dense wooded vegetation at the southern part of the study site.

The Principal component analysis (fig. 3) and Ordination (fig. 4) shows that the 
ecosystem of the study site is not stable yet. ings of the animals, while few were This can be observed from the clustering of encountered during the wet season. Along the animal species together in an attempt to make the best use of the environment. This may be due to the fact that the Strict Nature Reserve is recently demarcated and requires some time to settle away from the previous land use pattern of the area. The bulk of animal species wthin transects, combed during the survey were encountered during the dry season. This could be due to the fact that the environment is more open at this time of the year, enabling more sightthe transects, gradients, distribution of most of the species were closely tied to the season and are related either in the movement or other activity pattern, but some other also show a wide dispersion from the effect of the major component i.e dry season. Animals such as Cephalqus speeies Lepus capensis, some Arvicauthus nilctious and Thronomys swindarianus are in this group. These were found at the extremes of dry and wet season within the space.

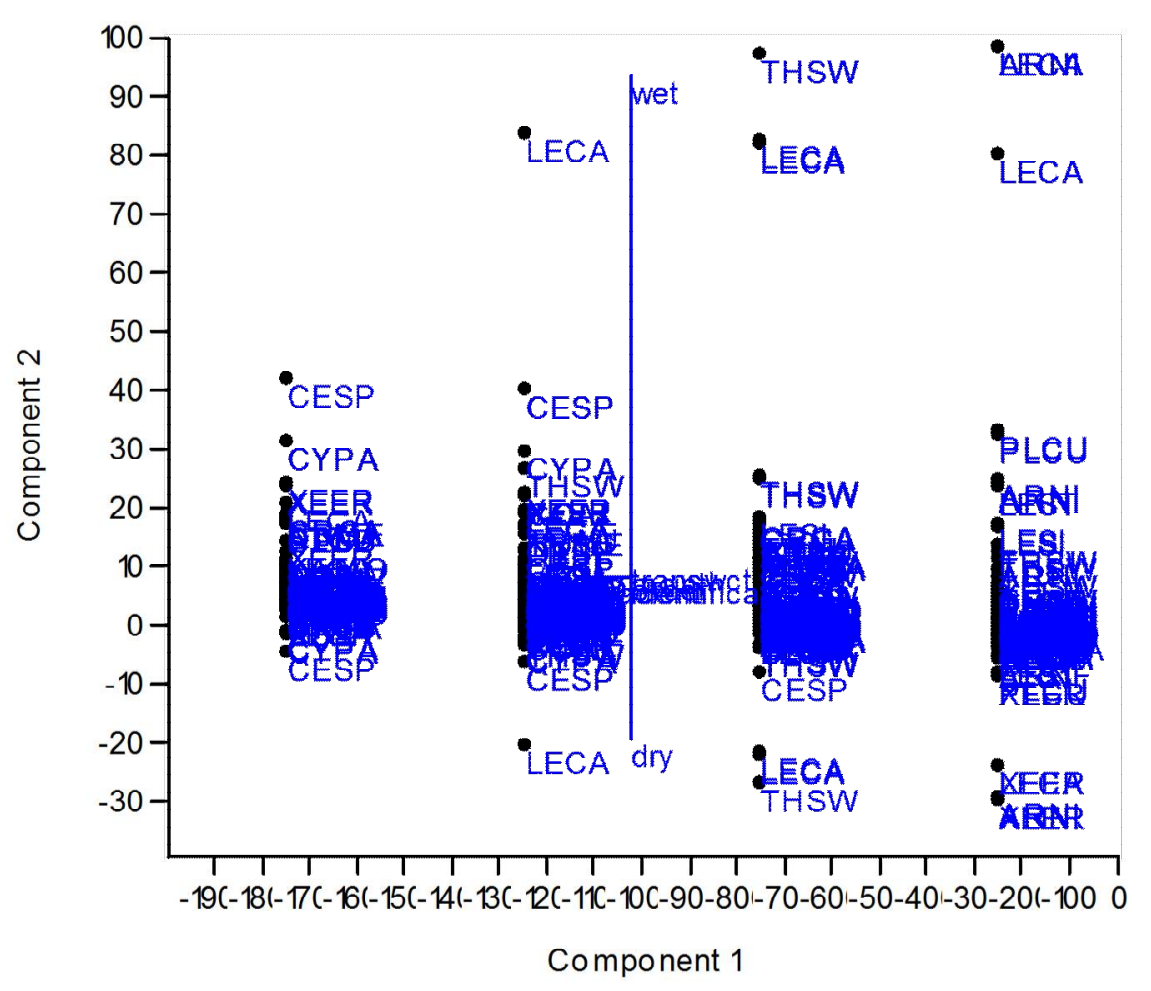

Fig.3: Principal Component Analysis of the distribution of Vertebrate species encountered in the Study Site 


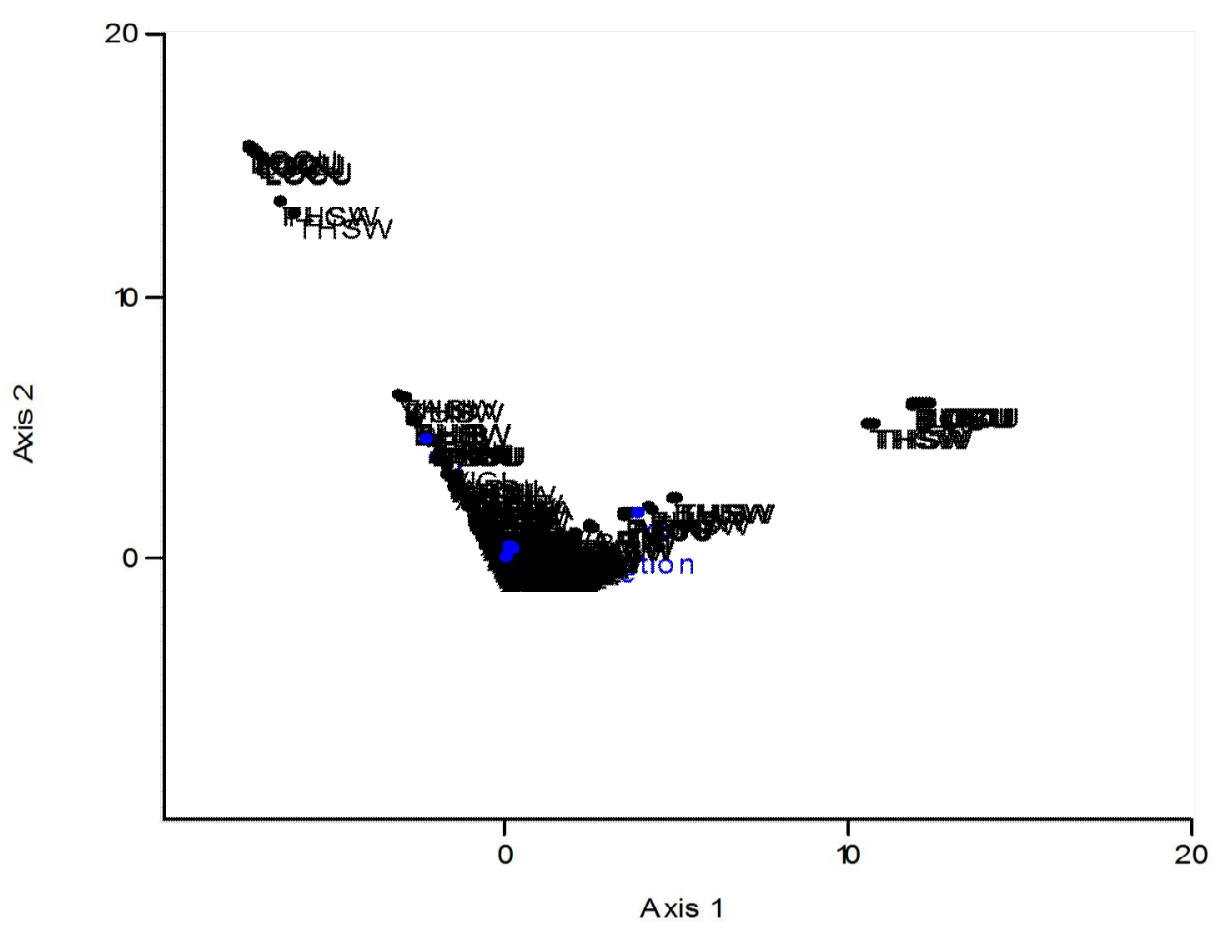

Fig.4: Ordination Diagram of Vertebrate in the Study Site

Ordination of animal species distribution in transects and season (fig. 5 and 6) revealed that the gradation is discontinuous but concentrated in the ordination space at around 12.0'clock and 3.0'clock and between 9-12 0'clock again. What this translates into is that every animal species that are found within the same quarter space are close and have almost the same factors influencing their distribution. Within the same quarter it was also noticed that Lonhura aullata and Thryonoms swindeianus are closer and a bit separated from the bulk, thus it can be suspected that a kind of ecological or biological relationship is occurring between them. Relationship between the animal species and environmental variables measured (seasons) indicate a very strong association between the factors and animal species thus, distribution, performance and survival of the species may be directly influenced by these variables.

Gradient distribution of animal species in wet season indicative of the point of contact with the animal along the transect gradient as well as the abundance values of the animal species encountered. The least abundance value of animal species (5.0) was 
encountered within the quadrant 1750 while (11.00) was encountered in quadrant 1750 the highest (102) was found in quadrant but the highest abundance of (99.00) was 250, so also in the dry season, the least found within 750 gradient.

Row and Column Points

\section{Symmetrical Normalization}

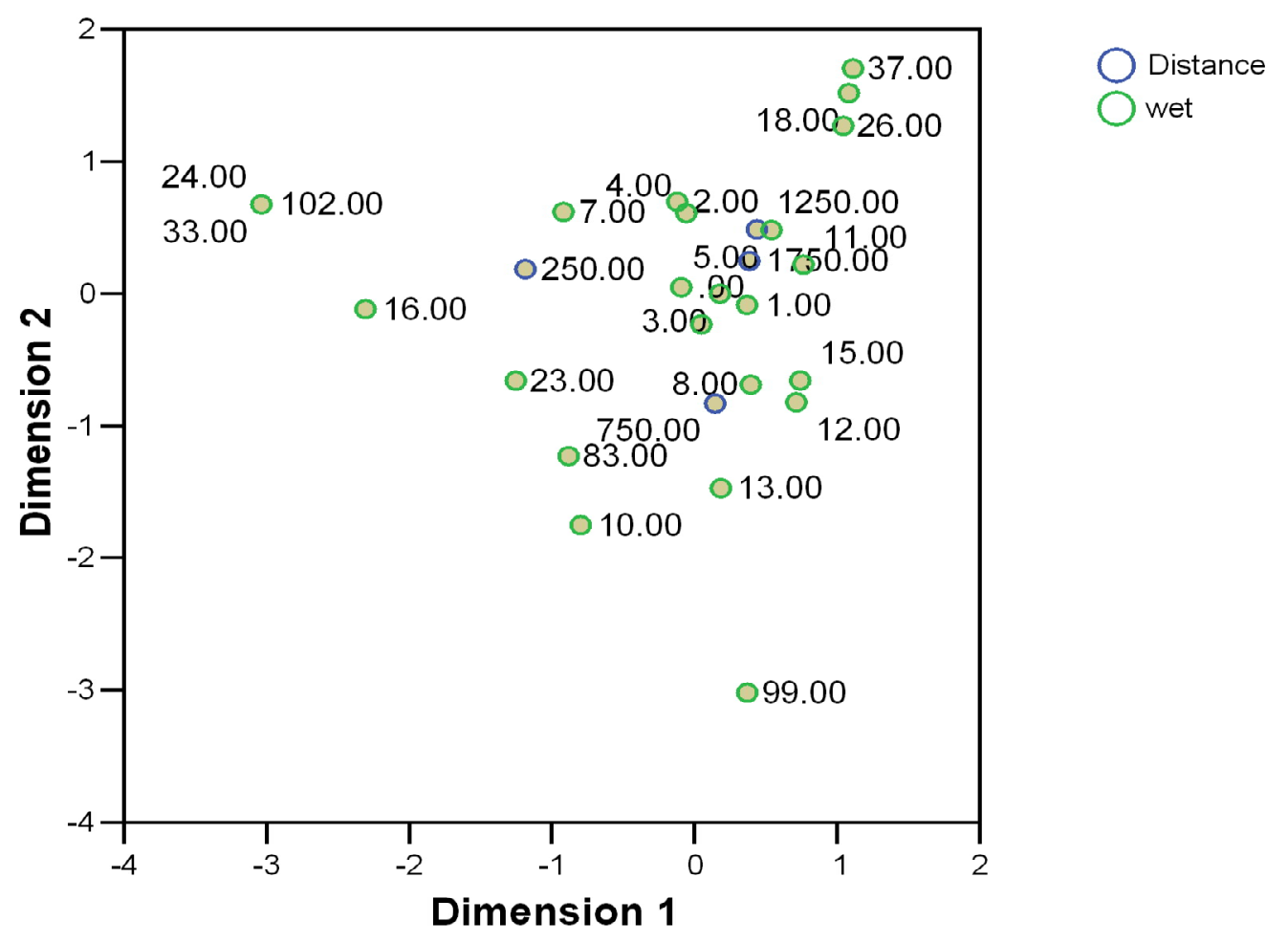

Fig.5: Sighting of Vertebrates According to Distance from Transects in the Wet Season 
Row and Column Points

\section{Symmetrical Normalization}

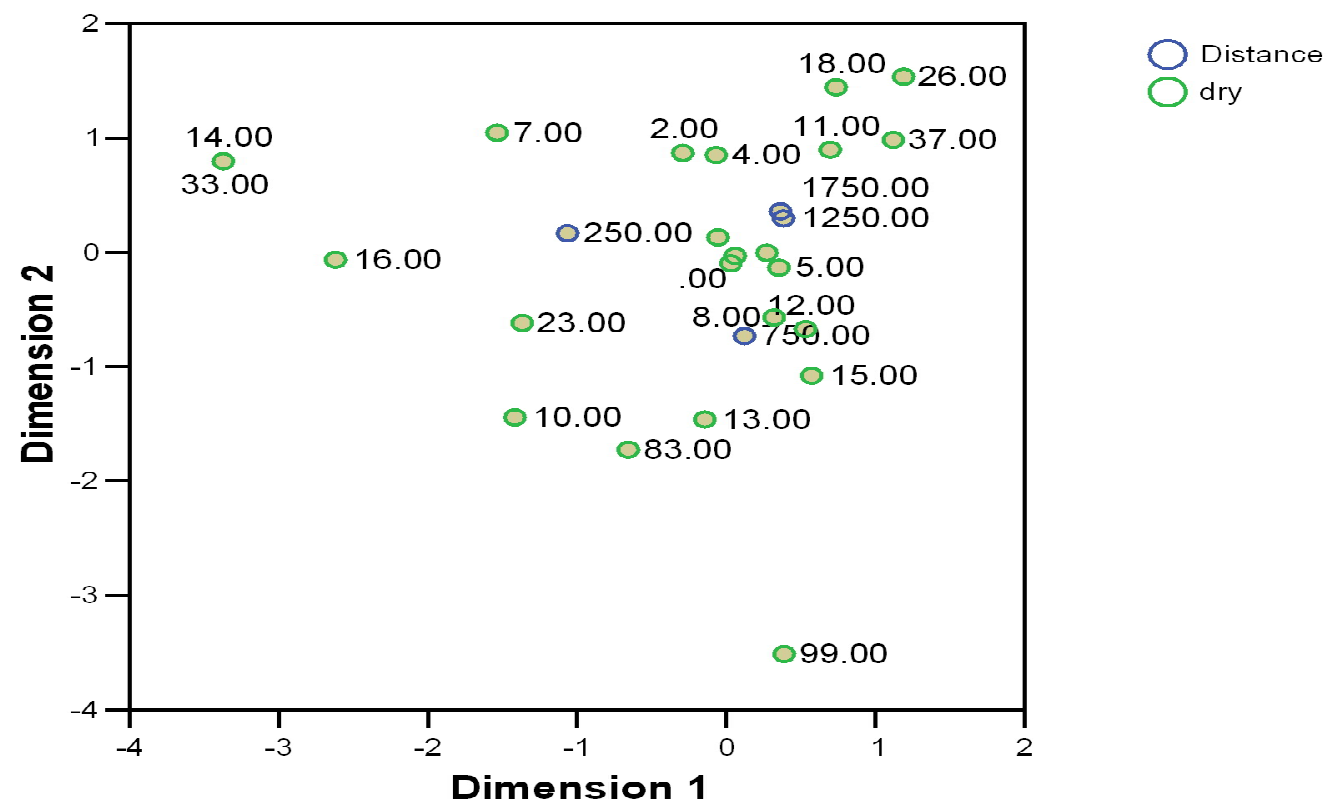

Fig.6: Sighting of Vertebrates According to Distance from Transects in the Dry Season

Table 6: Average Frequency of Plants in the Study Area

\begin{tabular}{lllll}
\hline Plant Specie & Frequency & Percent & $\begin{array}{l}\text { Valid } \\
\text { Percent }\end{array}$ & $\begin{array}{l}\text { Cumulative } \\
\text { Percent }\end{array}$ \\
\hline Acalypha ciliate & 8 & .7 & .7 & .8 \\
Afzelia Africana & 10 & .9 & .9 & 1.8 \\
Albizia lebeck & 2 & .2 & .2 & 1.9 \\
Albizia zygia & 1 & .1 & .1 & 2.0 \\
Alchornea cordifolia & 10 & .9 & .9 & 3.0 \\
Alstonia boonei & 14 & 1.3 & 1.3 & 4.3 \\
Amaranthus hybridus & 20 & 1.9 & 1.9 & 6.1 \\
Anacardium occidentalis & 2 & .2 & .2 & 6.3 \\
Anchomaiamis difformis & 15 & 1.4 & 1.4 & 7.7 \\
Andropogon gayanus & 22 & 2.0 & 2.0 & 9.7 \\
Andropogon tectorum & 22 & 2.0 & 2.0 & 11.8 \\
\hline
\end{tabular}

J. Agric. Sci. \& Env. 2017, 17(2):50-80 


\begin{tabular}{|c|c|c|c|c|}
\hline Annona senegalensis & 5 & .5 & .5 & 12.2 \\
\hline Anogeisus leiocarpus & 5 & .5 & .5 & 12.7 \\
\hline Anthoclesta vogelii & 3 & .3 & .3 & 13.0 \\
\hline Antiaris Africana & 6 & .6 & .6 & 13.5 \\
\hline Aspilia Africana & 18 & 1.7 & 1.7 & 15.2 \\
\hline Astonia boonei & 4 & .4 & .4 & 15.6 \\
\hline Azadirachta indica & 1 & .1 & .1 & 15.6 \\
\hline Barhania monodora & 3 & .3 & .3 & 15.9 \\
\hline Bidiens pilosa & 8 & .7 & .7 & 16.7 \\
\hline Blighia welwetchii & 8 & .7 & .7 & 17.4 \\
\hline Boerhavia coccinea & 14 & 1.3 & 1.3 & 18.7 \\
\hline Boerhavia diffussa & 8 & .7 & .7 & 19.4 \\
\hline Borreria veticulata & 4 & .4 & .4 & 19.8 \\
\hline Bridelia ferruginea & 1 & .1 & .1 & 19.9 \\
\hline Bridelia feruguinea & 30 & 2.8 & 2.8 & 22.7 \\
\hline Bridelia micrantha & 16 & 1.5 & 1.5 & 24.2 \\
\hline Bridellia micrantha & 6 & .6 & .6 & 24.7 \\
\hline Canthium volgeri & 2 & .2 & .2 & 24.9 \\
\hline Carica papaya & 6 & .6 & .6 & 25.5 \\
\hline Carpolobia lurea & 11 & 1.0 & 1.0 & 26.5 \\
\hline Casia mimosoides & 2 & .2 & .2 & 26.7 \\
\hline Casia podocarpa & 6 & .6 & .6 & 27.2 \\
\hline Cassia mimosoides & 9 & .8 & .8 & 28.1 \\
\hline Cassia podocarpa & 9 & .8 & .8 & 28.9 \\
\hline Ceiba pentandra & 1 & .1 & .1 & 29.0 \\
\hline Centrosema puebescen & 15 & 1.4 & 1.4 & 30.4 \\
\hline Chromolaena odoratum & 25 & 2.3 & 2.3 & 32.7 \\
\hline Cissampelos micronantha & 6 & .6 & .6 & 33.2 \\
\hline Cissus arguata & 1 & .1 & .1 & 33.3 \\
\hline Cleome viscose & 11 & 1.0 & 1.0 & 34.4 \\
\hline Cnestis ferruginea & 1 & .1 & .1 & 34.4 \\
\hline Cochlospermum planchonii & 2 & .2 & .2 & 34.6 \\
\hline Coehlospermum planchoni & 16 & 1.5 & 1.5 & 36.1 \\
\hline Cola millenii & 8 & .7 & .7 & 36.9 \\
\hline Combretum hispidum & 12 & 1.1 & 1.1 & 38.0 \\
\hline Combretum molle & 18 & 1.7 & 1.7 & 39.6 \\
\hline Combretum nigerica & 2 & .2 & .2 & 39.8 \\
\hline Combretum racemosum & 6 & .6 & .6 & 40.4 \\
\hline Combretum zenkerii & 8 & .7 & .7 & 41.1 \\
\hline
\end{tabular}




\begin{tabular}{|c|c|c|c|c|}
\hline Commelina benghalensis & 8 & .7 & .7 & 41.9 \\
\hline Commelina nodiflora & 15 & 1.4 & 1.4 & 43.2 \\
\hline Corchorus olitoriuos & 9 & .8 & .8 & 44.1 \\
\hline Cussonia barterii & 9 & .8 & .8 & 44.9 \\
\hline Cymbopogon giganteus & 6 & .6 & .6 & 45.5 \\
\hline Cynodon dactylon & 4 & .4 & .4 & 45.8 \\
\hline Cynometra megallophylla & 8 & .7 & .7 & 46.6 \\
\hline Cyperrus articularius & 7 & .6 & .6 & 47.2 \\
\hline D aniella olliveri & 21 & 1.9 & 1.9 & 49.2 \\
\hline Delonix regia & 4 & .4 & .4 & 49.5 \\
\hline Desmodium salutolium & 6 & .6 & .6 & 50.1 \\
\hline Detarium macrcapum & 2 & .2 & .2 & 50.3 \\
\hline Diplazium samatii & 7 & .6 & .6 & 50.9 \\
\hline Elaeis guineensis & 2 & .2 & .2 & 51.1 \\
\hline Eleusine indica & 13 & 1.2 & 1.2 & 52.3 \\
\hline Entada abicinica & 1 & .1 & .1 & 52.4 \\
\hline Entanda Africana & 4 & .4 & .4 & 52.8 \\
\hline Eragrostis tremula & 4 & .4 & .4 & 53.1 \\
\hline Euphorbia hirta & 4 & .4 & .4 & 53.5 \\
\hline Euphorbia laterflora & 5 & .5 & .5 & 54.0 \\
\hline Ficus capensis & 17 & 1.6 & 1.6 & 55.6 \\
\hline Ficus exasperate & 21 & 1.9 & 1.9 & 57.5 \\
\hline Ficus sur & 1 & .1 & .1 & 57.6 \\
\hline Ficus sycommorus & 9 & .8 & .8 & 58.4 \\
\hline Funfumia elastic & 6 & .6 & .6 & 59.0 \\
\hline Gardenia aqualla & 4 & .4 & .4 & 59.4 \\
\hline Gardenia rubiscens & 3 & .3 & .3 & 59.6 \\
\hline Holarrhena floribunda & 3 & .3 & .3 & 59.9 \\
\hline Hymenocardia acida & 12 & 1.1 & 1.1 & 61.0 \\
\hline Hypocrata pallens & 1 & .1 & .1 & 61.1 \\
\hline Hyptis suaveolens & 1 & .1 & .1 & 61.2 \\
\hline Imperata cylindrical & 17 & 1.6 & 1.6 & 62.8 \\
\hline Indigofera capitata & 4 & .4 & .4 & 63.1 \\
\hline irvingia wombolu & 10 & .9 & .9 & 64.1 \\
\hline Jatropha curcas & 7 & .6 & .6 & 64.7 \\
\hline Lantana camara & 6 & .6 & .6 & 65.3 \\
\hline Lantema camoma & 7 & .6 & .6 & 65.9 \\
\hline Lonchocarpus cyacems & 3 & .3 & .3 & 66.2 \\
\hline Lonchocarpus sericens & 1 & .1 & .1 & 66.3 \\
\hline Macarange barrteri & 7 & .6 & .6 & 66.9 \\
\hline Magaritaria discoides & 4 & .4 & .4 & 67.3 \\
\hline Malacantha alnifolia & 2 & .2 & .2 & 67.5 \\
\hline
\end{tabular}


A.L.A SHOTUYO , O A. JAYEO LA AND I.A. AYODELE

\begin{tabular}{|c|c|c|c|c|}
\hline Mangifera indica & 1 & .1 & .1 & 67.6 \\
\hline Mucuna prurens & 1 & .1 & .1 & 67.7 \\
\hline Myrianthus arboreus & 14 & 1.3 & 1.3 & 69.0 \\
\hline Nuclea latifolia & 1 & .1 & .1 & 69.1 \\
\hline Occimum canon & 4 & .4 & .4 & 69.4 \\
\hline Occimum gratissimum & 8 & .7 & .7 & 70.2 \\
\hline Olax secopoides & 7 & .6 & .6 & 70.8 \\
\hline Panieum maximum & 13 & 1.2 & 1.2 & 72.0 \\
\hline Parinari glabra & 6 & .6 & .6 & 72.6 \\
\hline Parinari polyandra & 4 & .4 & .4 & 73.0 \\
\hline Parinari robusta & 4 & .4 & .4 & 73.3 \\
\hline Parkia bicolor & 17 & 1.6 & 1.6 & 74.9 \\
\hline Parkia biglobasa & 7 & .6 & .6 & 75.6 \\
\hline Parkia biglobosa & 8 & .7 & .7 & 76.3 \\
\hline Parkia biglobossa & 6 & .6 & .6 & 76.9 \\
\hline Paspalum conjugatum & 9 & .8 & .8 & 77.7 \\
\hline Paspalum nonathum & 2 & .2 & .2 & 77.9 \\
\hline Pauridiantah hirttela & 6 & .6 & .6 & 78.4 \\
\hline Pauridiantha hirttela & 3 & .3 & .3 & 78.7 \\
\hline Pavetta corymbosa & 1 & .1 & .1 & 78.8 \\
\hline Pennisetum pedicellatum & 19 & 1.8 & 1.8 & 80.6 \\
\hline Prosopis Africana & 8 & .7 & .7 & 81.3 \\
\hline Psarospermum febrifuga & 8 & .7 & .7 & 82.0 \\
\hline Securidaea longipendicula & 12 & 1.1 & 1.1 & 83.1 \\
\hline Sema hirsute & 2 & .2 & .2 & 83.3 \\
\hline Senna hirsute & 7 & .6 & .6 & 84.0 \\
\hline Sinolax crucicina & 1 & .1 & .1 & 84.1 \\
\hline Smilax kruciana & 3 & .3 & .3 & 84.4 \\
\hline Solanum eriantum & 12 & 1.1 & 1.1 & 85.5 \\
\hline Solanum macrocarpum & 6 & .6 & .6 & 86.0 \\
\hline Solenostrenum monostachyc & 8 & .7 & .7 & 86.8 \\
\hline Spandias mombim & 14 & 1.3 & 1.3 & 88.1 \\
\hline Sphenocentron jollyanum & 6 & .6 & .6 & 88.6 \\
\hline Spondias mombim & 2 & .2 & .2 & 88.8 \\
\hline Sterculia tragacantha & 10 & .9 & .9 & 89.7 \\
\hline
\end{tabular}


HABITAT USE STRATEGY OF VERTEBRATES IN AN ...

\begin{tabular}{lllll}
\hline Stragia spp & 5 & .5 & .5 & 90.2 \\
Syndrella nodiflora & 10 & .9 & .9 & 91.1 \\
Tectona grandis & 10 & .9 & .9 & 92.0 \\
Tephrosia braceolata & 10 & .9 & .9 & 93.0 \\
Tephrosia pedicellata & 10 & .9 & .9 & 93.9 \\
Terminalia glaucescens & 18 & 1.7 & 1.7 & 95.6 \\
Vernonia amygdalina & 10 & .9 & .9 & 96.5 \\
Vipellaria paradoxa & 8 & .7 & .7 & 97.2 \\
Vitellaria paradoxa & 4 & .4 & .4 & 97.6 \\
Vitex doniana & 9 & .8 & .8 & 98.4 \\
Vittelaria paradoxum & 1 & .1 & .1 & 98.5 \\
Waltheria indica & 16 & 1.5 & 1.5 & 100.0 \\
Total & 1080 & 100.0 & 100.0 & \\
\hline
\end{tabular}

The disappearance of many plant species due to human activities is depleting the world's genetic resources and is putting man's heritage of biodiversity under serious threat. There is therefore the urgent need to preserve genetic diversity including plant resources of known and unknown economic importance which will guarantee the availability of all potentials for use in the benefit of our children and grandchildren (Olowokudejo, 1987). The human race in their quest for economic development and improvement of their conditions of life must come to terms with the realities of resource limitations and the carrying capacity of ecosystem must also take account of the needs of future generation. This is the central message to modern conservation.

Biological diversity must be treated seriously as a global resource, be indexed, used and above all preserved. Three circumstances make it imperative for this to be given an unprecedented urgency particularly in West Africa. Firstly, exploding human populations are seriously legion. Secondly, science is discovering new uses for plants and animals, thus encourag- ing the degrading of the environment at an alarming rate. Thirdly, much of the diversity is being irreversibly lost through extinction caused by the destruction of natural habitats, which occurs more in Africa than elsewhere (Wilson, 1988). D asman \&al., (1973) agreed that forest exploitation leads to the extinction of animals and plants whose genetic resources are of considerable value to future generations.

Forest depletion has destabilized the natural environment and eroded genetic resources throughout the southern part of Nigeria in order to meet the sustenance of the population and financial requirements of government i.e. the social, economic, demographic and political needs of the people. Exploitation of forests therefore appears to be split about vegetation depletion which is considered as inevitable considering the above. According to some scientists (Harvey and Hallet, 1977) it may not be beneficial to conserve resources for future generation at all costs because the future demands, aspirations, lifestyles and needs of rural people cannot be adequately defined now. Must we then wait for the needs to be defined before we conserve? 
Definitely not, because all of these genetic resources would have disappeared before the needs are identified. As such, conservation is basic to human welfare and indeed to human survival.

Lack of conservation measures will amount to an increase in the number of endangered species and this will ultimately result in extinction, which is the gradual but sure elimination of taxa (Allaby, 2010). Many of the species that are already endangered are faced with the risk of eventual extinction if human activities such as land development, logging and pollution are not checked. G bile et al. (1981) revealed that about four hundred and eighty plant species of the Nigerian flora have been described as endangered or rare, out of which many of these are being studied at the Forestry Research Institute of Nigeria, Ibadan.

\section{CONCLUSION}

The ecosystem of the strict nature reserve is not yet stable. More time is needed for the site to settle away from the previous land use pattern of the area. Food and cover requirements abound in the study area, which explains the availability of a variety of fauna species. The distributions of most of the vertebrate species were closely tied to the seasons. There is a strong association between the environmental variables and animal species thus; distribution, performance and survival of the species are directly influenced by these variables.

In other for the strict nature reserve to stabilize, human activities such as hunting, burning, cultivation etc that could put the resources under threat should be totally controlled.

\section{REFERENCES}

Allaby, M.2010. Oxford D ictionary of Ecology. New York. NY. Oxford University Press. 432pp

Dasmann, R. F. 1985. Commercial Use of Game Animals on a Rhodesian Ranch,Wildifepp 7 -14.

Dasman, R. F., Milton, J. P., Freeman, P. H. 1992. Ecological principles for economic development. Wetlands Conservation Conference for Southern Africa. Proceedings of the Southern Africa Development Coodination Coference Held in Gaborone, Botswana, 3-5 June 1991. Matiza T and Chabwela H.N (Eds), IUCN, Gland Switzerland. $\mathrm{X}+224 \mathrm{pp}$

Dickman, C. R., Doncaster, C. P. 1989. The ecology of small mammals in urban habitats populations in a patchy environment. J. Anim E@. 56, 629-640.

Ewer, D. W. 1969. Form and Function in the Grasscutter. Paul Eleck, London. Pp 1 27.

Gbile, Z. 0., Ola-Adams, B. A., Spladoye, M. O. 1981. List of Rare \species of the Nigerian Flora. Research Paper (Forerst series). No. 47. Forest Research Institute of Nigeria, Ibadan.

Hansson, L., Fahrig, L and Memian, G. 1995. Mosaic Landscapes and Ecological Processes. Chapman and Hall, London. Pages 1-26.

Happold, D. C. D. 1973. The distribution of Large Mammals in West Africa. Mammalian 37: 88-93.

Happold, D. C. D. 1987. Mammals of 
HABITAT USE STRATEGY OF VERTEBRATES IN AN ...

Nigeria. Oxford University Press; pp 10-16.

Harvey, B., Hallett, J. D. 1977. Environment and Society: An Introductory Analysis. Macmillan. 163pages.

Kupchella, E. J., Hyland, M. C. 1993. Environmental Science. Prentice Hall Inc. N. J. 426pages.

Olowokudejo, J. D. 1987 . 'Medicinal Plants Used as Vermifuges in Nigeria and their Conservation'. Jamal of Econmic and TaxanomicBdany. 9: 459-466.

Onadeko, S. A., A. J. Meduna 1985. Increasing Conflicts between Fulani Grazers and Wildlife protection Areas. Proceedings of the $14^{\text {th }}$ Annual conference of $F$. A. N.( O. O. Okaroand S. A. Afumape(Ed)). Pp 175-197

Richards, P. W. 1952. The tropical rainforest. Cambridge University Press. 450pages

Robberts, M. B. V. 1986. Biology. A functional Approach. Nelson Thomes. 693 pages.
Saunders, W. B., Davis, L. E., Knight, R. L. 1987. Sympatic species of Nautilus (N. Pompilius and N. Serdiaulatus) in the Admiralty Islands, Papau New G uinea. Nautilus 101: 93-99

\section{Saunders, D. A. , Hobbs, R. J., Margules,} C.R. 1991. Biological Consequences of Ecosystems fragmentations, Conservation Bidog, Vol. 5. No. 1. Pp. 18-32.

Shotuyo, A. L. A. 2011. Assessment of Vertebrate Diversity in Alabata Nature Reserve Abeokuta South West Nigeria. Unpublished, Ph.D. Thesis University of Ibadan. 189pages.

Turner, I. M. 1996. Species loss in fragments of tropical rainforest: a review of the evidence. Jaumal of Applied Ecology 33, 200209.

Turner, I. M., Carllet, T. R. 1996. The Conservation value of small, isolated fragments of lowland tropical forest. Trends Eब Evd. 11 (8): 330-3.

Wilson, E. O. 1988. Biodiversity. The National Academic Press. 538pages.

(Manuscipt reeived 6thJune, 2017; accepted 12th Novenber, 2014). 